\title{
O REFLEXO DA EDUCAÇÃO AMBIENTAL NO EXERCíCIO DA CIDADANIA AMBIENTAL POR MEIO DA TUTELA JURISDICIONAL
}

\author{
THE REFLECTION OF ENVIRONMENTAL EDUCATION IN THE \\ EXERCISE OF ENVIRONMENTAL CITIZENSHIP BY \\ JURISDICTIONAL GUARANTEE
}

\begin{abstract}
ANI CRISTINA BARIQUELLO
Mestranda em Direito Empresarial e Cidadania - Centro Universitário Curitiba UNICURITIBA. Curitiba - PR. email: ani.c.bariquello@gmail.com
\end{abstract}

JOSÉ EDMILSON DE SOUZA-LIMA Pesquisador e docente do PPGMADE-UFPR e do Centro Universitário Curitiba UNICURITIBA. Curitiba - PR. email: zecaed@hotmail.com

\section{RESUMO}

A atual Constituição da República, promulgada em 1988, após a Conferência de Estocolmo de 1972 e da Conferência das Nações Unidas para o desenvolvimento Humano em 1983, está do começo ao fim permeada pelo princípio da sustentabilidade e, via de consequência, elevou o meio ambiente ao status de direito fundamental a ser garantido a todos e preservado por todos. Outros encontros de nações ocorreram nestes 30 anos de vigência da Constituição, dois deles no Brasil nos anos de 92 e 2012. Não se logrou, contudo, que o meio ambiente seja sobrepujado com relação ao desenvolvimento econômico. Questiona-se, assim quais os fatores da possível ineficiência da norma constitucional para garantir o 


\section{Personalidade Acadêmica Homenageada:}

Carlos Aurélio Mota de Souza (Universidade Ibirapuera - UNIB)

exercício da cidadania ambiental, com a finalidade de preservação do meio ambiente ecologicamente equilibrado por todos, sob a ótica da deficiência da educação ambiental, prevista tanto na constituição, quanto alçada como princípio na Conferência das Nações Unidas sobre meio ambiente e desenvolvimento. Toma-se como ponto inicial para responder esta inquietante pergunta os julgados no Estado do Paraná entre os anos de 2015 e 2018, com vistas a verificar por meio das demandas que espécie de violação ambiental é levada às Cortes e qual a tutela jurisdicional esperada pelos cidadãos. Assim, após a seleção dos julgados por meio de filtro disponibilizado no site do Tribunal de Justiça, será realizada a análise documental que consiste primeiramente na leitura da ementa, para verificar se o julgado trata, ou não, sobre questões ambientais. Feita esta triagem, após identificação dos julgados pertinentes à pesquisa, procede-se à leitura da íntegra do relatórios e do voto, com a finalidade de registrar em planilha os seguintes dados: a) Órgão Julgador; b) Desembargador que proferiu o voto que prevaleceu no julgado; c) espécie de recurso; d) número e estado identificador do recurso; e) as partes envolvidas; f) espécie da ação originária; g) fato que deu causa à ação originária; g) pedido formulado; h) o resultado do julgado; i) data do julgamento; j) elementos conceituais que definem meio ambiente na decisão. No segundo momento, a partir das informações catalogadas será realizada a análise qualitativa, mediante a observação do fato que motivou o processo, compreensão de meio ambiente e resultado da ação - dentre outros elementos, que poderão ser ampliados no decorrer da pesquisa. A partir da análise desses pontos, acredita-se que será possível verificar se as decisões refletem em que medida o exercício da cidadania ambiental é afetado em razão da existência ou insuficiência das políticas públicas voltadas à educação ambiental.

PALAVRAS-CHAVE: Meio Ambiente; Cidadania Ambiental; Jurisprudência; Educação ambiental. 
Personalidade Acadêmica Homenageada:

Carlos Aurélio Mota de Souza (Universidade Ibirapuera - UNIB)

\section{REFERÊNCIAS}

FADUL, David Malheiro; SOUZA-LIMA, José Edmilson. Decisões civilizatórias e campo ambiental: a norma como parte do emaranhado. Desenvolvimento e Meio Ambiente, v. 39, 2016.

Fadul, David Malheiro; SOUZA-LIMA, J. E. Contornos do conhecimento ambiental: uma contribuição do realismo jurídico. Revista Jurídica, 3(32), 383-403, 2013.

RODRIGUEZ, José Rodrigo. Como decidem as cortes?: para uma crítica do direito (brasileiro). Rio de Janeiro: Editora FGV, 2013.

Ross, Alf. Direito e Justiça. São Paulo: Edipro, 2000. 